\title{
THE EFFECT OF L2 LISTENING TEXTS ADAPTED TO THE DIGITAL STORY ON THE LISTENING LESSON
}

\author{
Dr. Fatih TANRIKULU \\ ORCID: 0000-0002-6730-0353 \\ Faculty of Education \\ Kahramanmaras Sutcu Imam University \\ Kahramanmaras, TURKEY
}

Received: 20/12/2018 Accepted: 05/08/2019

\begin{abstract}
The study conducted as the action research model aimed to identify the effect of use of new story form, digital storytelling (DST) as a product input in listening lessons on listening lessons. Working group of the research consists of higher education undergraduate foreign students mostly financed by UN (N:49). The two-step procedure covers a twelve-week-process of six weeks each. The first step was applied on students studying at C1 level and the second step was applied on students studying at B1 level. During the procedure, 40 texts in DST format were used for listening lesson. Researcher diary, student diary and focus group discussions were used as data collection tools. The data obtained were analyzed with Nvivo 11 qualitative data analysis program. Themes were created by coding and categorizing the data. As a result of the research, it is seen that digital storytelling has a positive effect on the development of listening skills, positively affects learning and is more effective compared to listening lessons taught with voice recordings and increases student motivation.
\end{abstract}

Keywords: Digital storytelling, listening skill, action research.

\section{INTRODUCTION}

Listening is a significant skill both in daily life and in education life (Cigerci \& Gultekin, 2017). Different techniques, materials and tools are utilized in order to improve this important skill. One of these tools is tales and stories, the most used old narration types (Barclay, 2012). However, changes in technology brought about different needs along with it (Lotherington \& Ronda, 2014). Technology, by affecting the role of story as one of traditional types in education environment, created its new form DST (Bozdogan, 2012). This new type, as the technological face of story, is one of the multimedia technologies which provides the possibility to share a story in digital media (Yussof, Abas \& Paris, 2012). It is known that DST, one of multimedia technologies and similar technologies help development of listening skills (Barclay, 2012). In this regard, DST can be used as an alternative application in listening education (Ramirez Verdugo, \& Alonso Belmonte, 2007; Morris, 2011). A new option can be presented to language teachers in order to develop listening skills in educational environment (Abdollahpour \& Maleki, 2012).

\section{Tale, Story and Listening Education}

Tales and stories can be effective listening tools to develop both mother tongue and the second langue learning skills. As the communication between narrator and listener is based on listening skill, stories help focusing (Abdollahpour \& Maleki, 2012). Thanks to its attention-grabbing character due to its dynamic nature (Hull, \& Katz, 2006), narrator directs the listener to a world full of visions and voices by linking reality of real life to the imagination of the listener (Foley, 2013). At the same time, story, which is based on speaking and listening, can also have a significant contribution to language education. By its very nature, it provides the opportunity to listen and speak the target language more frequently enabling more chances to apply the target language (Dollar \& Tolu, 2015). Storytelling can be seen as a practical and strong language teaching tool especially for language learning (Yussof, Abas \& Paris, (2012). It provides the opportunity to apply the four skills; reading, writing, listening and speaking for the students (Dollar \& Tolu, 2015). 


\section{Tradional Story And Digital Story}

The changing technology and the different communication skills require change and development to meet the needs of web 2.0 environments (Lotherington \& Ronda, 2014). Development and change in technology created new forms of telling and listening stories which are a part of tradition (Bauman, 1986). DST as one of these forms is one of the multimedia technologies to be used for storytelling (Yussof, Abas \& Paris, 2012). DST constitutes innovative opportunities and areas for students by expanding storytelling opportunities (Morris, 2011). It prepares the way for broadcasting thoughts and stories in a place where other people can listen, see and hear online (Fasi, 2011). DST, described as a narrator communicating between narrator and audience with its multimedia structure (Yuksel-Arslan, 2013), makes the storytelling enjoyable and delightful with its colorful, graphic, vocal, video and interactive narrations (Yussof, Abas \& Paris, 2012). DST can be seen as the combination of traditional storytelling and technology (Normann, 2011; Nguyen, 2011). This multimedia-based application created with the inspiration from traditional story consists of both elements of story and multimedia. It is based on tradition and different from story in some aspects (Dorner, Grimm \& Abawi 2002; Morris, 2011). In DST, the audience can affect and shape the story as they are active participants (Dorner, Grimm \& Abawi, 2002; Miller, 2014). While traditional story is being presented to live audience by a narrator in the same physical environment, DST narration is presented via multimedia and narrator plays both the role of the author and the listener (Morris, 2011; Foley, 2013 DST helps developing stories through technology (Dorner, Grimm \& Abawi, 2002). It provides the possibility for students to reach out to other people in digital environment. DST gives the chance to broadcast thoughts and stories online where other people can listen, see and hear (Fasi, 2011). It is seen that technological dimension adds a significant potential to traditional storytelling (McLellan, 2006). Story, as a useful tool both in traditional and digital aspects (Fokides, 2016), is used as a functional application to develop listening skills.

\section{Effect of DST to Listening}

Mobile technology and multimedia provide the opportunity to develop materials for listening education in various forms now (Hsu, Hwang, Chang, \& Chang, 2013). These opportunities can be used in developing listening skills and can enrich language education (Meskill, 1996). DST as one of the new opportunities of multimedia is an effective tool to develop students' listening skills (Ramirez Verdugo \& Alonso Belmonte, 2007). This educational application can be an alternative for developing listening skills (Morris, 2011) and can make the listening activities easier in education environment (Ramirez Verdugo, \& Alonso Belmonte, 2007). It gives the opportunity to practice listening skills (Wang \& Zhan, 2010) by meeting communicational needs such as telling and listening (Simsek 2012). Thus, it can be used as a rich learning-teaching technique in acquiring listening skills (Kurudayioglu \& Bal, 2014).

At the editing scenario text and presentation stage of DST creation, both DST creators and the audience actively uses listening (Banazevsky, 2002; Van \& Gills, 2005; Yamac \& Ulusoy, 2006; Bran, 2009; Miller 2009; Slvyester \& Greenedge, 2009; Gubrium, 2010; Wang \& Zhan, 2010; Gordon, 2011; Nguyen 2011; Simsek 2012; Yang \& Wu, 2012; Bozdogan 2012; Bumgarner, 2012; Hull \& Katz, 2006; Ozkoz \& Elola 2016; Fokides 2016). At the process of DST creation, voice is recorded, and records are listened, and these records are edited according to feedbacks (Bumgarner, 2012; Castañeda, 2013; Ozkoz \& Elola, 2016). These activities in the process positively affects development of listening skills (Tsou, Wang \& Tzeng, 2006; Ramirez Verdugo, \& Alonso Belmonte, 2007; Ohler, 2006; Davis \& McGrail, 2009; Wang \& Zhan, 2010; Robin, Mcneil \& Yuksel, 2011; Robin, \& McNeil, 2012; Yussof, Abas \& Paris, 2012; Pardo, 2014; Kurudayioglu \& Bal, 2014; Ozkoz \& Elola, 2016). After the process, well-chosen DST' can be useful in developing listening skills (Abdollahpour \& Maleki, 2012).

\section{Using DST in a Foreing Language}

Multimedia applications are important tools (Brett, 1995) to develop listening as a significant skill area in foreign language teaching (Long, 1989; Vandergrift, 2007). Multimedia in various forms can enrich language education (Meskill, 1996) by presenting listening materials (Hsu, Hwang, Chang, \& Chang, 2013). Multimedia tools can develop listening skills by creating an environment in a foreign language ((Meskill, 
1996; Jones \& Plass, 2002). As one of these multimedia tools DST' supporting foreign language development (Abidin, Pour-Mohammadi, Souriyavongsa, Tiang, \& Kim, 2011) is reflected to the studies carried out (Ramirez Verdugo, \& Alonso Belmonte, 2007; Normann, 2011; Robin, McNeil, \& Yuksel, 2011; Castañeda 2013; Pardo, 2014; Yoon, 2016; Diaz, 2016). During the process of DST creation, second language learning is supported while the records are edited (Normann, 2011). Therefore, in the foreign language classes where DST is used, development of student skills can be expected (Yoon, 2012; Kurudayioglu, 2014), motivation provider side of video can be an advantage for language education (Meskill, 1996). Stories, by developing child's listening and focusing skills, can motivate students, make lessons enjoyable and can help having a positive attitude towards foreign languages (Loukia, 2006; Abdollahpour \& Maleki, 2012). Use of DST, as the technological state of story, in their activities can be effective on listening skills (Tatli \& Arzugul Aksoy, 2017). It is known that chosen DST' develop student's listening skills (Ramirez Verdugo, \& Alonso Belmonte, 2007). However, the studies examining the effects of DST on listening are concentrated more on its effect during the process. There are very few studies on DST' effect on listening as an output (RamirezVerdugo \& Belmonte, 2007; (Abidin, Pour-Mohammadi, Souriyavongsa, Tiang, \& Kim, 2011; Cigerci \& Gultekin 2017). In listening lessons in line with content of the lesson, there are no studies on DST use. This study aims to examine the effects of DST', specifically created with reference to texts for listening lesson, on listening lesson and skill. In service of this goal, answers to the following questions have been sought:

1. What are the effects of the use of DST on L2 listening education on students?

2. How is the use of digital story reflected in the learning environment in L2 listening lesson?

\section{METHOD}

This study is designed in action research model among qualitative research patterns. Action research is intended to improve a current situation or fix a bad situation. It aims to improve education by changing educational environment and acting according to results of change (Kemmis, 1992:25).

\section{Determining a Focal Area}

The researcher, who previously carried out research on DST, saw that DST' multimedia feature has a significant place in language teaching. He thought that the listening training would be more effective by supporting with multimedia as it is only based on voice and addresses to one sensory organ. The researcher shared his opinion with technology-language experts as well. Furthermore, he discussed whether this study would be useful by sharing it with other instructors working at the center. The author, who got positive feedbacks, considering researches on DST' language learning, listening education foreign language education as second language, decided to use DST in listening lessons.

\section{Research Participants}

The study, by the nature of action research, has been conducted with more than one participant. Researcher, experts, validity committee, course teacher, participant students and focus group students constituted the working group of this research. The researcher is the one who developed the application and is in the role of participant observer. Experts are three instructors from the faculty of education. Experts are instructors who have studies on education area as well as being experienced on qualitative research. Members of the validity committee comprises of three instructors who are working in TOMER with the researcher and have at least one-year experience in teaching Turkish to foreigners. Committee members, making regular meetings, gave opinion and made recommendations on the course of the research. There are course teachers among these instructors. Course teacher is the teacher who gives the listening lesson in the center. During the first and the second phases, different teachers were used. It has been put into practice in a class taught by one of the experienced teachers on a voluntary basis. Students are foreign students studying at university $(\mathrm{N}$ : $23+26=49)$. These students are mostly the Syrian refugees financed by the UN. The students, after learning Turkish in the language teaching center, continue their education in their own departments. Students of the first phase comprises of 23 people who are learning C1 level language in the class number 5 during 2016- 
2017 school year, second phase student group consists of 26 people who are learning B1 level language in the class number 7 during 2017-2018 school year. The information on the countries and genders of the students are given in the graphs. Focus group students comprises of students chosen among students in the application class on voluntary basis. Focus group discussions were made with 6 students including 4 males and 2 females in the first phase while the number of students was 6 including 1 female and 5 males in the second phase.

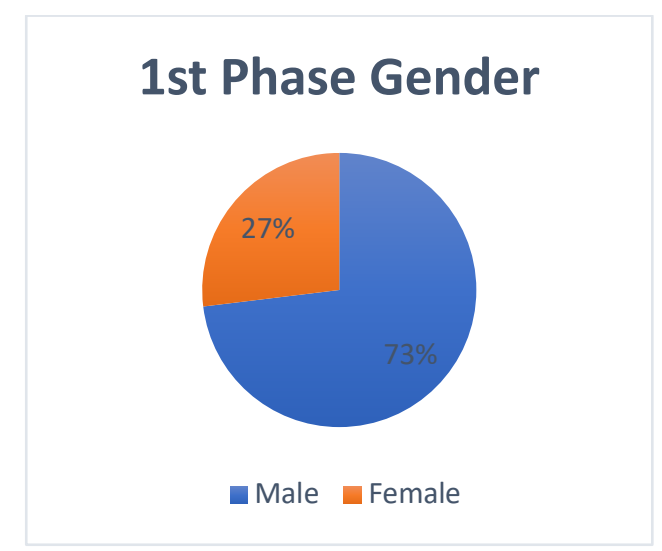

\section{2nd Phase Gender}

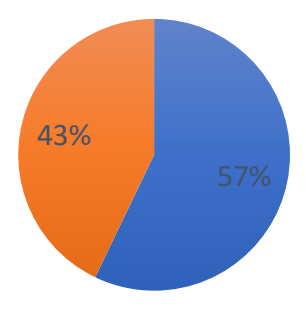

- Male Female

Figure 1. Gender
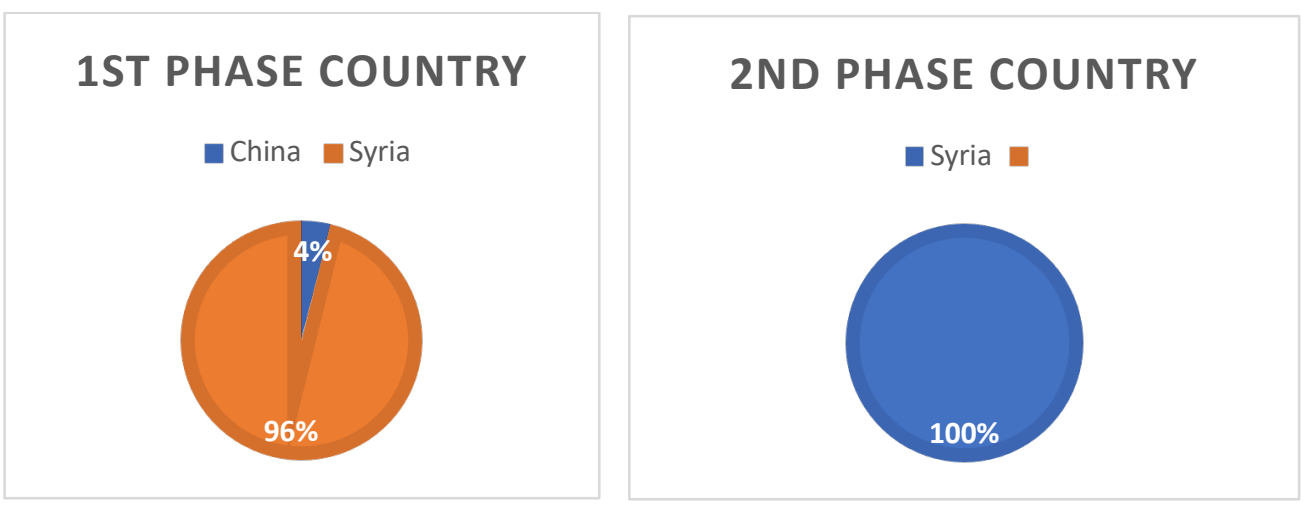

Figure 2. Country

\section{Literature Review}

According to the literature review on DST, it is seen that DST has a significant place in language teaching and there are many researchers in this field. By DST' nature, it is noted that most of the studies were made on writing skills. It is notable that there are less studies on listening skill compared to other language skills. Furthermore, the studies were on the effect of DST creation process on language. It is seen that there are very few studies on the effect of DST output product on listening. It is found that there are no studies specifically on DST' listening education. From the literature review, the thought that DST' multimedia feature maybe successful on listening skill has been effective on conducting this study. Literature review started before the research continued during the research process. 


\section{Defining an Action Plan}

The action research should be planned thoroughly in order to be successful. It has been focused on why and how the application can be developed (Taylor, Wilkie \& Baser, 2006). This can only be achieved through a very good planning. While preparing an action plan, the aims are clearly introduced and goals are listed. The types of data to be gathered and data gathering process were taken into consideration (Koshy, 2005). Considering these matters, plan of the action research is defined as in Figure 4.

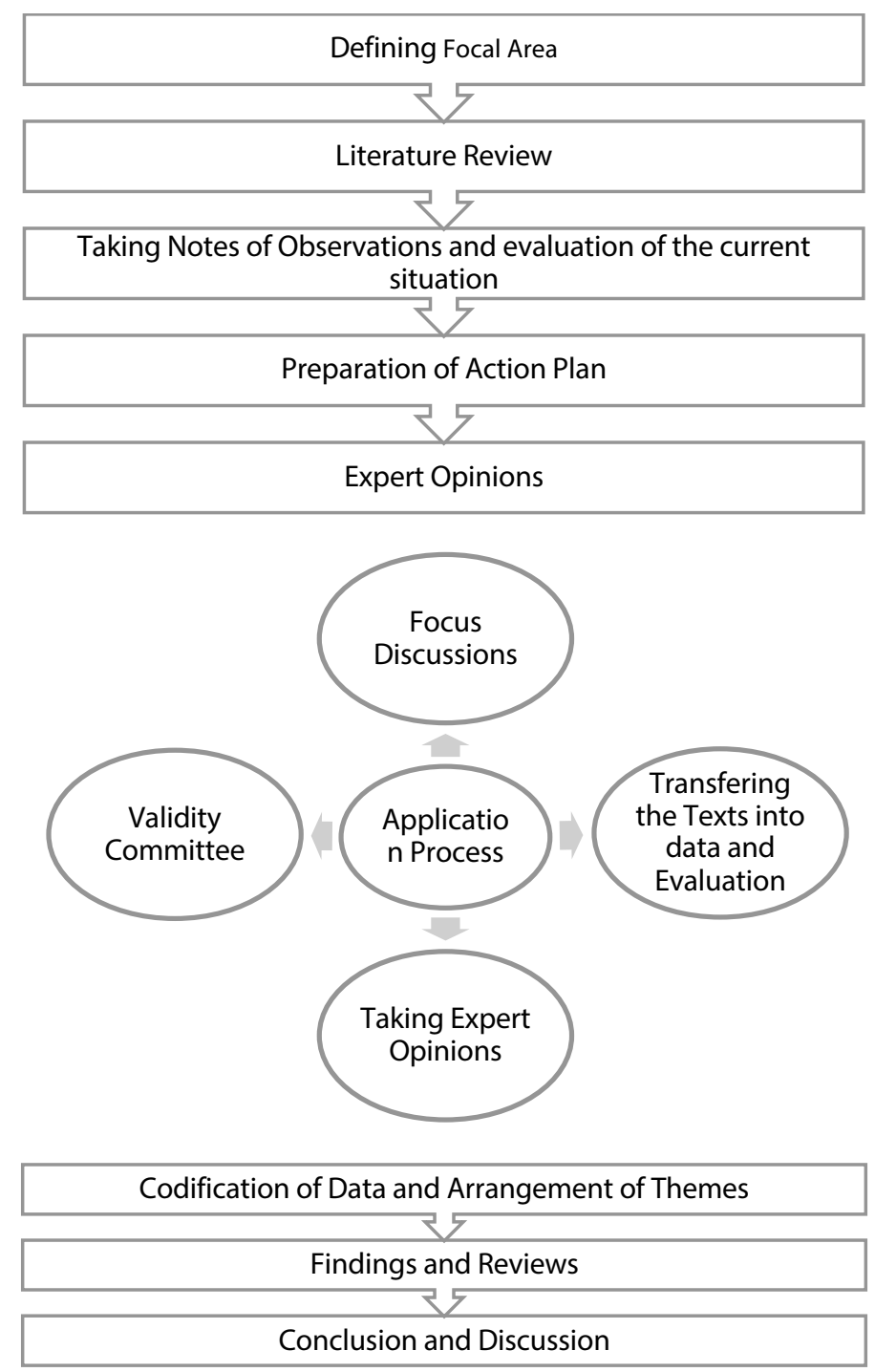

Figure 3. Action research plan 


\section{Data Collection}

Data collection process of the research is given in detail in Table 1 .

Table 1. Data collection process of the research

\begin{tabular}{|c|c|c|c|}
\hline \multirow{16}{*}{ 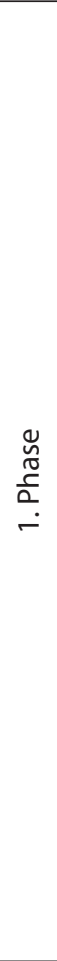 } & Before Application & & Literature Review \\
\hline & Before Application & May 2017 & Preparation of Action Plan \\
\hline & Before Application & May 2017 & Observations made before the research \\
\hline & Before Application & May 2017 & Taking expert opinions \\
\hline & Before Application & May 2017 & $\begin{array}{l}\text { Determining the participants, creating the committee, } \\
\text { preparation of action plan }\end{array}$ \\
\hline & Before Application & May 2017 & Preparation of digital stories to be used in listening \\
\hline & Before Application & 06 June 2017 & Focus Group Discussion \\
\hline & 1. Week & 13 June 2017 & Practice lesson, writing the 1 st student diaries \\
\hline & 2. Week & 20 June 2017 & Practice lesson, writing the 2 nd student diaries \\
\hline & 2. Week & 22 June 2017 & $\begin{array}{l}\text { 1. validity committee meeting, having the in- class records } \\
\text { watched, reading the diaries }\end{array}$ \\
\hline & 3. Week & 27 June 2017 & Practice lesson \\
\hline & 4. Week & 04 July 2017 & Practice lesson, writing the 3 rd student diaries \\
\hline & 4. Week & 6 July 2017 & $\begin{array}{l}\text { 2. validity committee meeting, having the in- class records } \\
\text { watched, reading the diaries }\end{array}$ \\
\hline & 5. Week & 11 July 2017 & Practice lesson \\
\hline & 5. Week & 12 July 2017 & Focus Group Discussion \\
\hline & 6. Week & 18 July 2017 & Practice lesson, writing the 4th student diaries \\
\hline \multirow{14}{*}{ 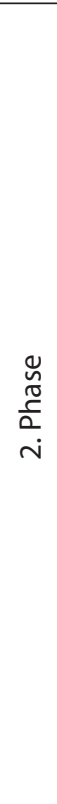 } & Before Application & February 2018 & Revision of the 1st phase \\
\hline & Before Application & February 2018 & $\begin{array}{l}\text { Determining the participants, creating the committee, } \\
\text { preparation of action plan }\end{array}$ \\
\hline & Before Application & $\begin{array}{l}\text { January-February } \\
2018\end{array}$ & Preparation of digital stories to be used in listening \\
\hline & Before Application & & Focus Group Discussion \\
\hline & 1. Week & 26 February 2018 & First practice lesson \\
\hline & 2. Week & 02 March 2018 & Practice lesson, writing the 1 st student diaries \\
\hline & 2. Week & 05 March 2018 & $\begin{array}{l}\text { Validity committee meeting, having the class records watched, } \\
\text { reading the diaries }\end{array}$ \\
\hline & \multirow[t]{2}{*}{ 3. Week } & 09 March 2018 & Practice lesson, writing the 2 nd student diaries \\
\hline & & 12 March 2018 & Focus group discussion \\
\hline & 4. Week & 16 March 2018 & Practice lesson, writing the 3rd student diaries \\
\hline & 4. Week & 19 March 2018 & $\begin{array}{l}\text { Validity committee meeting, having the in- class records watched, } \\
\text { reading the diaries }\end{array}$ \\
\hline & 5. Week & 23 March 2018 & Practice lesson \\
\hline & 6. Week & 30 March 2018 & Practice lesson, writing the 4 th student diaries \\
\hline & 6. Week & & Focus Group Discussion \\
\hline
\end{tabular}

\section{1st Phase}

The researcher first identified the problem status. Before the research, he made observations on listening lesson. As he previously took place in these lessons, the researcher reflected his experiences to his observations. Observation and area notes were shared with the experts. At the same time they were shared with teachers giving lessons in the language center. After deciding the research, literature review was conducted. An action plan was prepared in line with the literature review, observations and expert opinions. Action plan was shared with the experts and committee and arranged according to the feedbacks and put into final form. As a result 
of the observations, area notes and discussions with the teachers, the class in which the research would take place was decided. The DST' to be used in the next phase were prepared. There are 20 listening texts in total for each phase. The listening texts into DST by using Movie Maker program. Texts turned into DST were rearranged by taking opinions of experts and committee. Before practice, there had been discussions with focus group students. The first practice lesson was made on June 13, 2017. At the end of the three-hourlesson, the students were asked to write a diary. During six-week-practice, 4 diaries were written. Following the two-week practice, after diaries, there had been a committee meeting. Diaries and short video records were shared with the committee. Practices and meetings continued in this way. One week before the end of the practice, focus discussion was conducted.

\section{2nd Phase}

Data of the 1st phase were revised, and deficiencies identified. Considering the opinion that it should be applied on students in low levels mentioned in phase 1, it is decided that the practice would be made with B1 level language learning students. In the 1st phase, negativities like fast speaking, some of the DST photos' being incompatible, students' preferring to look at the book more for fill-in-the-blank texts in listening activities were considered and deficiencies were tried to be fixed. During the 2nd phase practice, students were told that they can listen DST from voice while studying texts in fill-in-the-blank activities. Again, determination of participants and creation of the committee were made as in the 1st phase at this stage. In the 1st phase, the incompatibility of photos is tried to be fixed. Students of education faculty helped in DST conversion. DST' were presented to expert and arrangements were made. Before practice, focus discussion was made. The first practice was made on February 26, 2018. After the second week practice, diaries were kept and then the committee meeting was held. Short videos taken from the lessons were shared with the committee. The points indicated in the plan were made in the same way with the procedure in plan of the 1 st phase and data collection.

\section{Data Collection Tools}

Data was collected from the diaries, focus discussions, participant observations, video records, documents and literature (Stringer, 2007: 68).

\section{Student Diaries}

Participant students kept diaries during learning process (Kemmis \& McTaggart, 1992: 50). During the practice of each 6 weeks, each student kept 4 diaries. The diaries were kept after the practice lesson. Each diary was recorded as a separate word file. In first phase 46, in second phase 65, in total 111 diaries were included in codification.

\section{Researcher Diary}

Researcher diary is not only used for collection and analysis of data, but also used for following up the research process (Altrichter, Posch, Somekh \& Feldman, 2005). Diaries regularly kept after each lesson in order to reflect the research process and researcher observations were included in codification.

\section{Focus Interview}

Focus group discussions were made before the practice and during the practice process. Two discussions in the 1 st phase of the research, 3 discussions in the 2 nd phase of the research were made. The discussions made before the practice were not included in the codification. 1 focus discussion in 1st phase, 2 focus discussion $s$ in 2 nd phase was included in the codification. Six students, including 4 males and 2 females in the first phase and 6 students including 1 female and 5 males in the second phase were interviewed. 


\section{Data Analysis and Codification}

For data analysis, content analysis method was used. Nvivo 11 qualitative data analysis program was used for the analysis. During codification, words, word groups and sentences were selected as baseline. Names of the codes created based on students' expressions. In codification, for clearer reflection of student opinions, codes were given names which were very close to students' expressions. Although visuals and picture words were used in the same meaning, they were given different cryptonyms in order to reflect student's opinion much clearer. While the code in the same meaning was visual in the first phase, it was picture in the second phase. The first phase data were analyzed, codes and themes were created. These codes and themes were checked by two different expert academicians during qualitative data research and codes were put into final form after being arranged according to these feedbacks. Common views on the code list created in first phase were directly used in second phase. Unexampled codes were codified with a different name. These codes were categorized and gathered under a different theme (Stringer, 2007; Ekiz, 2009).

\section{Ethics}

After determining the practice class, the practice was discussed with the teacher who would apply it. Then, the practice was discussed with the students. How the application would continue, how it would end and how the data would be used were explained in details to the students. The students were assured that they would be able to give up at any phase of the application (Taylor, Wilkie \& Baser, 2006). A written consent was taken from the students stating that they had volunteered and allowed the use of the data obtained from the research.

\section{Reliability and Validity}

Data was collected from multiple sources in order to ensure reliability and precision of qualitative data (Naughton \& Hughes, 2009). In the research, 53 codes in the first phase, 74 codes in the second phase were codified from 127 different sources of researcher and student diaries and focus discussions. By getting 400 code frequencies from 126 different sources, triangulation was provided. In order to sustain reliability, codes and themes were verified by two expert instructors. In line with their views, the necessary amendments were made.

\section{FINDINGS}

In this section, the findings of the research are given. In this section, codes of 5 themes from data analysis and their ratios are given. Subtitles are determined in line with the theme obtained. In each theme, a graph showing the theme's ratio to all codes is given. Then, graphs of common codes and unexampled codes are given and they are explained.

\section{Theme of Its Effect to Learning}

\begin{tabular}{|c|c|c|c|c|}
\hline \multicolumn{5}{|c|}{ Its Effect on Learning Theme Graph } \\
\hline $100,00 \%$ & $38,17 \%$ & $54,28 \%$ & & $49,00 \%$ \\
\hline \multirow{2}{*}{$0,00 \%$} & \multicolumn{4}{|c|}{1} \\
\hline & 1st Phase & 2nd Phase & Average & \\
\hline
\end{tabular}

Figure 4. Its effect on learning theme graph 
196 codes were obtained under its effect on learning theme. 50 of these codes belong to the 1 st phase, 146 of them belongs to the 2 nd phase. The effect of this theme to the 1 st phase is $38.17 \%$ and the effect to the 2nd phase is $54.28 \%$, and the total effect on two phases is $49.00 \%$. This ratio corresponds to the half of the findings obtained from the research.

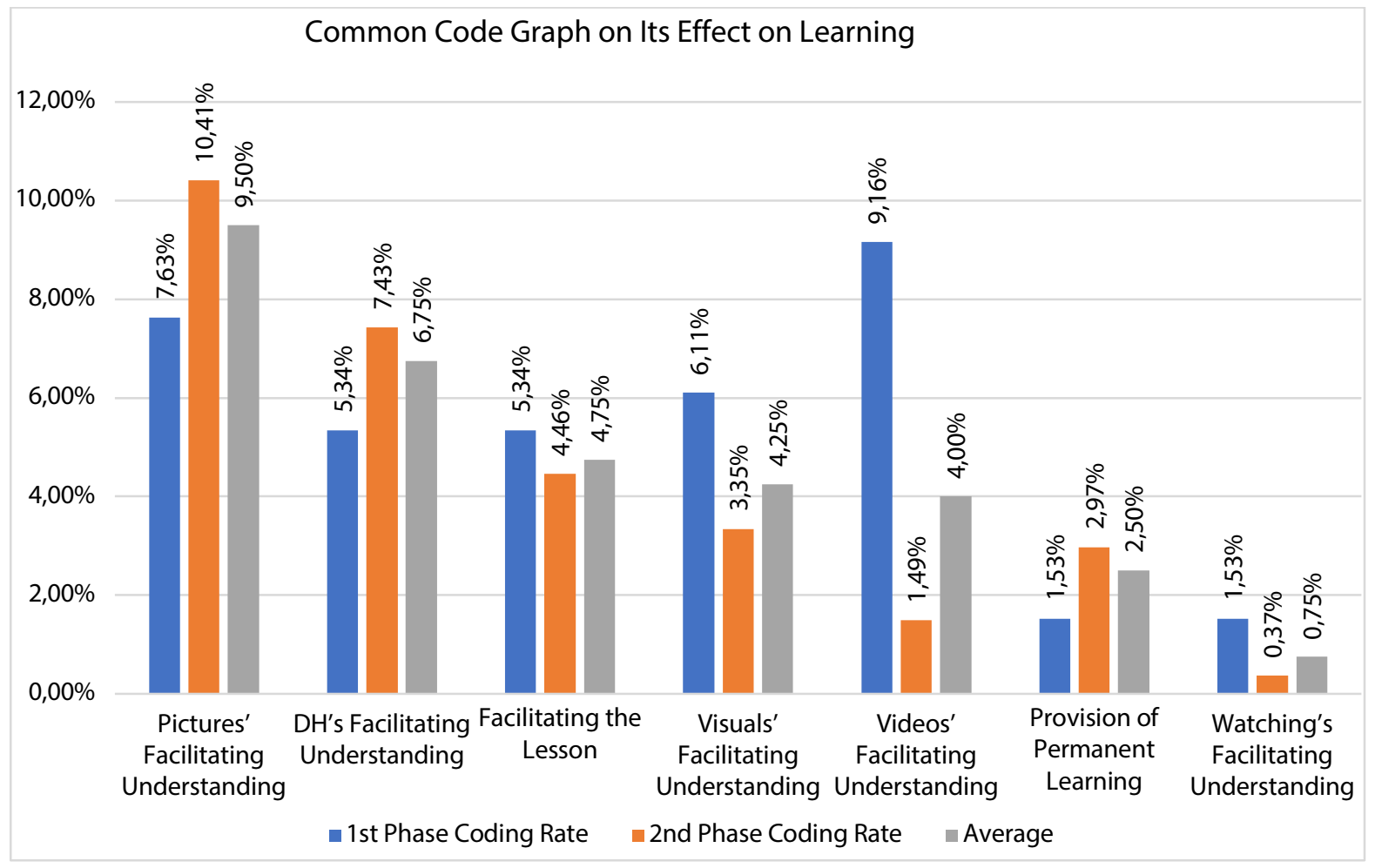

Figure 5. Common code graph on its effect on learning

Common codes in this theme generally comprise of views on DST' multimedia feature. Pictures' facilitating understanding is the second which effects the total most among all codes with a ratio of $9.50 \%$. This code's ratio to total codes in 1 st phase is $7.63 \%$, and $10.41 \%$ in second phase. DST' facilitating understanding code is among the ones with highest effect with $6.75 \%$. its ratio to total codes in 1 st phase is $5.34 \%$ while it is $7.43 \%$ in 2 nd phase. Facilitating the lesson code, with its $4.75 \%$ ratio, is one of the most effective ones on the average of all codes. Its ratio to total codes in 1 st phase is $5.34 \%$ while its ratio to total codes in the 2nd phase is $4.46 \%$. Visuals facilitating understanding is among most effective ones on the average of all codes with a ratio of $4.25 \%$. Its ratio to code total in 1 st phase is $6.11 \%$, while it is $3.35 \%$ in the second phase. Video's facilitating understanding is among most effective ones on the average of all codes with a ratio of $4.00 \%$. Its ratio to code total in 1 st phase is $9.16 \%$ while it is $1.49 \%$ in second phase. Provision of Permanent Learning code has the ratio of $2.50 \%$. Its ratio to code total in 1 st phase is $1.53 \%$, while it is $2.97 \%$ in second phase. Watching's facilitating understanding code has a ratio of $0.75 \%$. Its ratio to code total is $1.53 \%$ in 1 st phase, while its ratio to code total is $0.37 \%$ in 2 nd phase. 


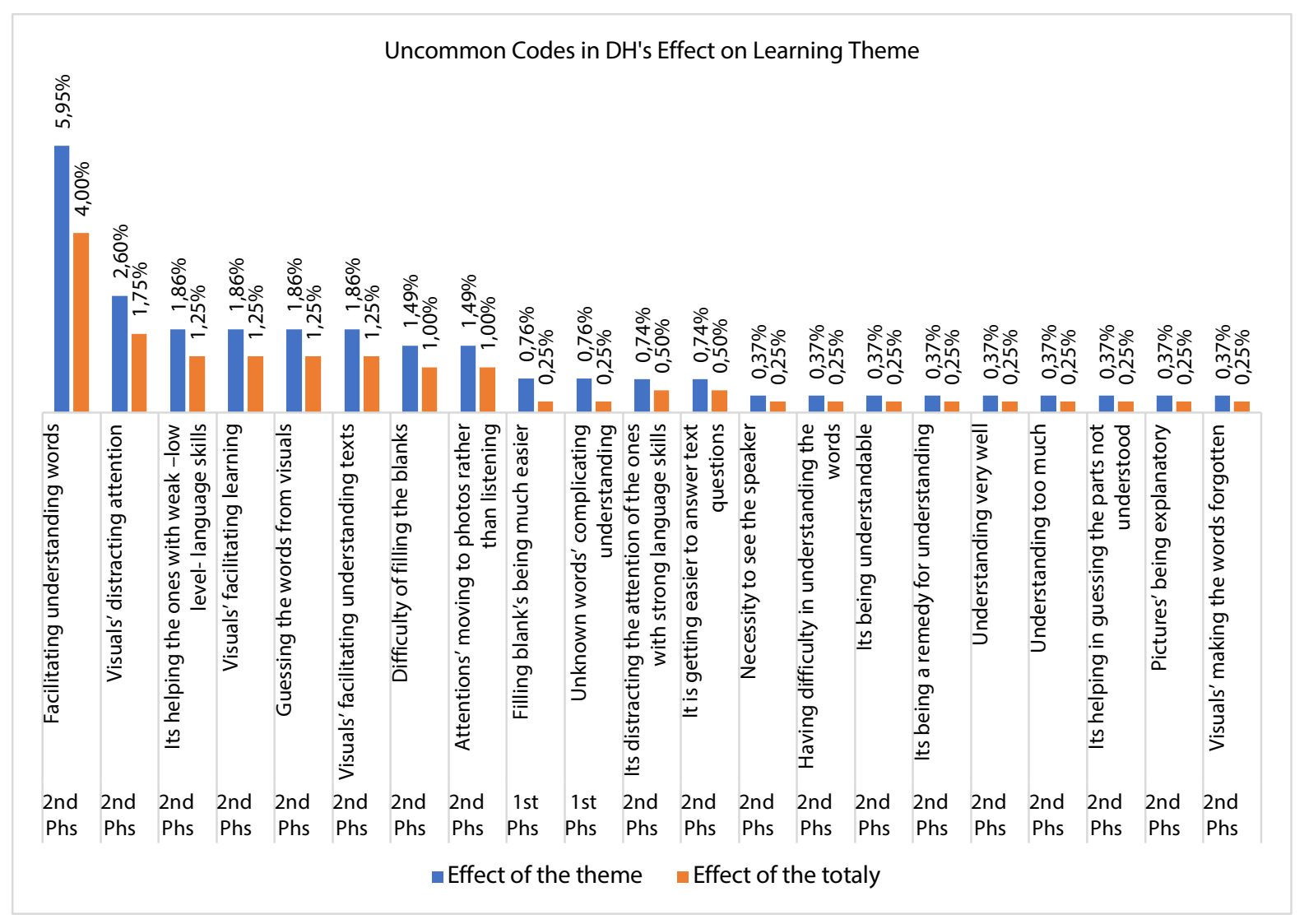

Figure 6. Uncommon codes in DST' effect on learning theme

The codes given in Graph 6 comprise of uncommon codes in 1st and 2nd phase in DST's Effect on Learning theme. 1st columns show the effect on code number in the phase it belonged to, 2nd columns shows its effect to total. Words' facilitating understanding is a code only in 2nd phase. This code is among the ones with high ratio to total code number. Its ratio to 2 nd phase code number is 5.95 , its effect to total code ratio is 4.00. Visuals distracting attention is a code which can be regarded as negative in this theme. Its ratio to the number of codes in 2 nd phase is $2.60 \%$, its ratio to number of total codes is $\% 1.75$. It is seen that uncommon codes graph comprises of codes reflecting multimedia feature of DST.

\section{Comparison Theme}

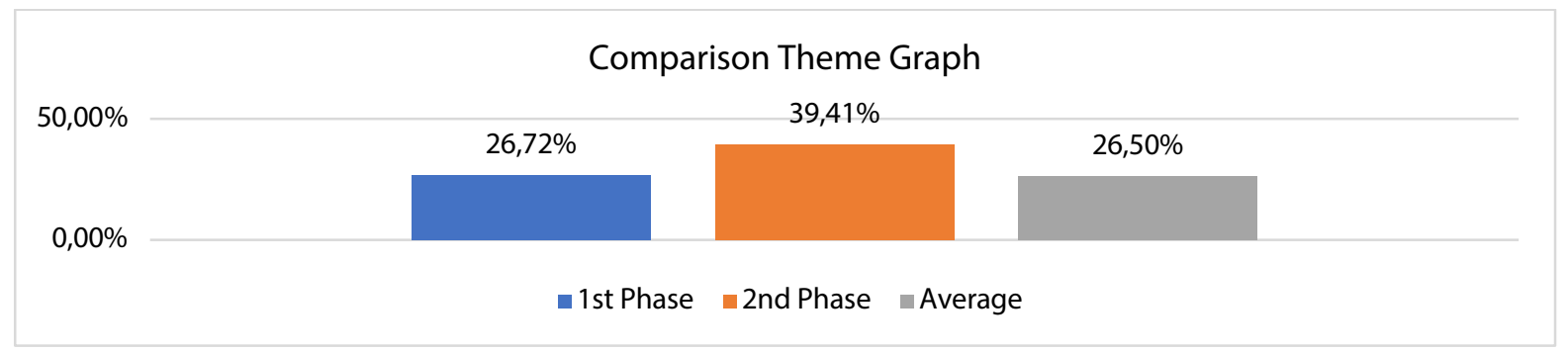

Figure 7. Comparison theme graph

Comparison theme contains student opinions which compare listening lesson with DST practice lesson. This theme is important as it reveals the situation before and after the practice. It clearly reveals the effectiveness of the practice by making comparison. 106 codes in total were obtained from comparison theme. This theme's 
ratio to total number of codes obtained in 1 st phase is $\% 26.72$, its ratio to total number of codes obtained in 2 nd phase is $\% 39.41$, and its ratio to total number of codes obtained in both phases is $\% 26.50$.

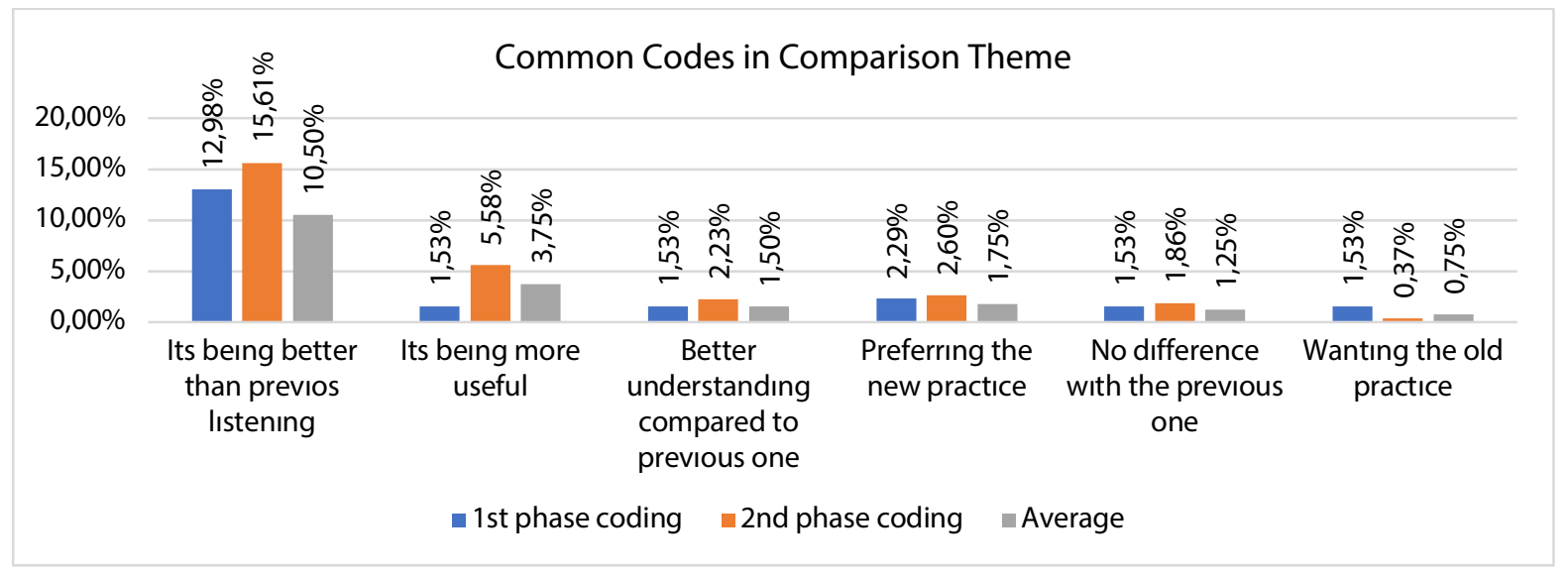

Figure 8. Common codes in comparison theme

In Figure 8 common codes in comparison theme are given. The code of being better than previous listening is the most effective on the total among all with the ratio of $10.50 \%$. This code's ratio to the ratio of total codes in 1 st phase is $12.98 \%$ and its ratio to the code number in 2 nd phase is $15.61 \%$. Being more useful is among the most effective codes on average of all codes with a ratio of $3.75 \%$. Its ratio to code total in 1 st phase is $1.53 \%$ and its ratio to code total in 2 nd phase is $5.58 \%$. Being better than the previous one is among the ones with normal effect on average total of all codes with a ratio of $1.50 \%$. Its ratio to code total in 1 st phase is $1.53 \%$ and its ratio to code total in 2 nd phase is $2.23 \%$. Preferring the new practice code is among the ones with normal effect on average total of all codes with a ratio of $1.75 \%$. Its ratio to code total in 1 st phase is $2.29 \%$ and its ratio to code total in 2 nd phase is $2.60 \%$. The code of no difference with the previous one is among the ones with normal effect on average total of all codes with a ratio of $1.25 \%$. Its ratio to code total in 1 st phase is $1.53 \%$ and its ratio to code total in 2 nd phase is $1.86 \%$. The code of requesting the old practice ha $0.75 \%$ effect. Its ratio to code total in 1 st phase is $1.53 \%$ and its effect to code total in 2nd phase is $0.37 \%$.

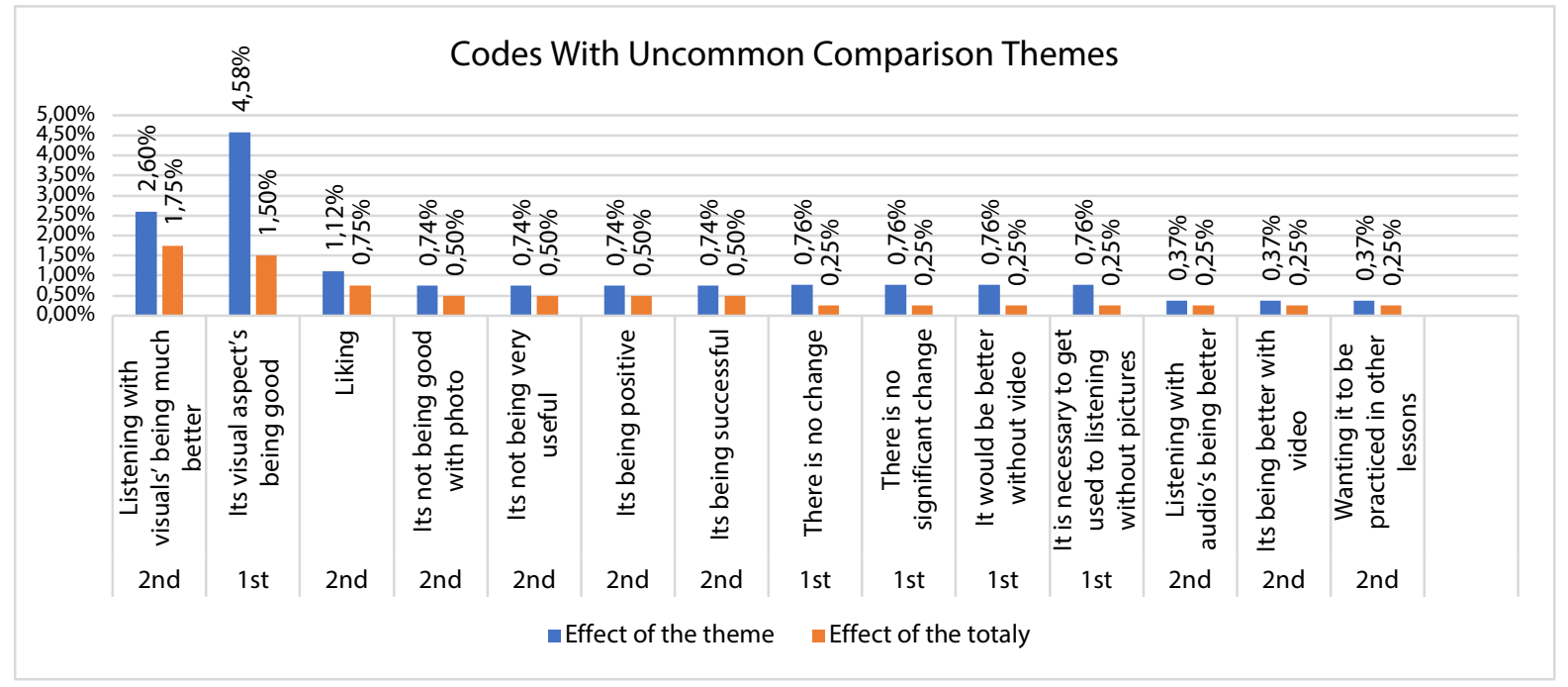

Figure 9. Codes with uncommon comparison themes 
Figure 9 comprises of uncommon codes in comparison theme. Listening with pictures' being better is a code which exists only in 2 nd phase. This code is among the ones with high ratio on total code number. Its ratio to the number of codes in 2 nd phase is $2.60 \%$ while its ratio to total code number is $1.75 \%$. Some part of the uncommon codes comprise of codes which reflects DST' multimedia feature. Apart from that, there are codes reflecting before and after the practice such as comparison of lessons, liking, its being useful, its being successful etc. In this graph, there are negative opinions against the practice despite it has low effect on the total. The codes as not being good with photo $0.50 \%$, not being very useful $0.50 \%$, no change $0.25 \%$, no significant change $0.25 \%$, better without video $0.25 \%$, willing to have the previous practice $0.25 \%$, necessity to get used to listening without picture and listening with audio's being better $0.25 \%$ are the codes with negative attitude towards practice. It is seen that these negative codes towards the practice has a minor effect on the ratio of total codes.

\section{High Motivation Theme}

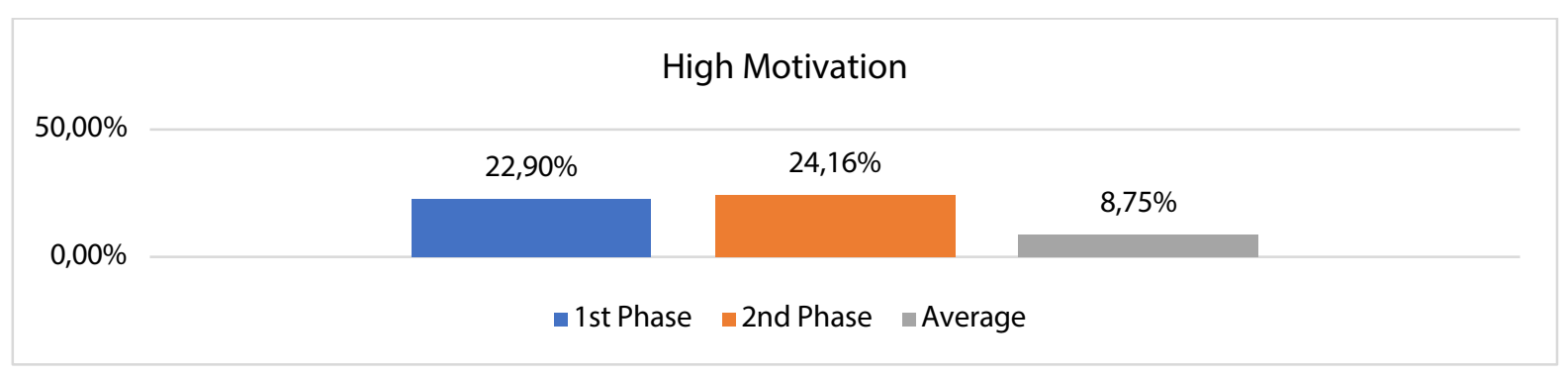

Figure 10. High motivation

High motivation theme comprises of opinions which shows the effect of practice on student motivation. The theme helps seeing the practice's effect on student. In high motivation theme, 65 codes in total were obtained. Ratio of this theme to total code number obtained in 1 st phase is $22.90 \%$ and its ratio to total code number obtained in 2 nd phase is $24.16 \%$, and its ratio to total number of codes obtained in two levels is $8.75 \%$.

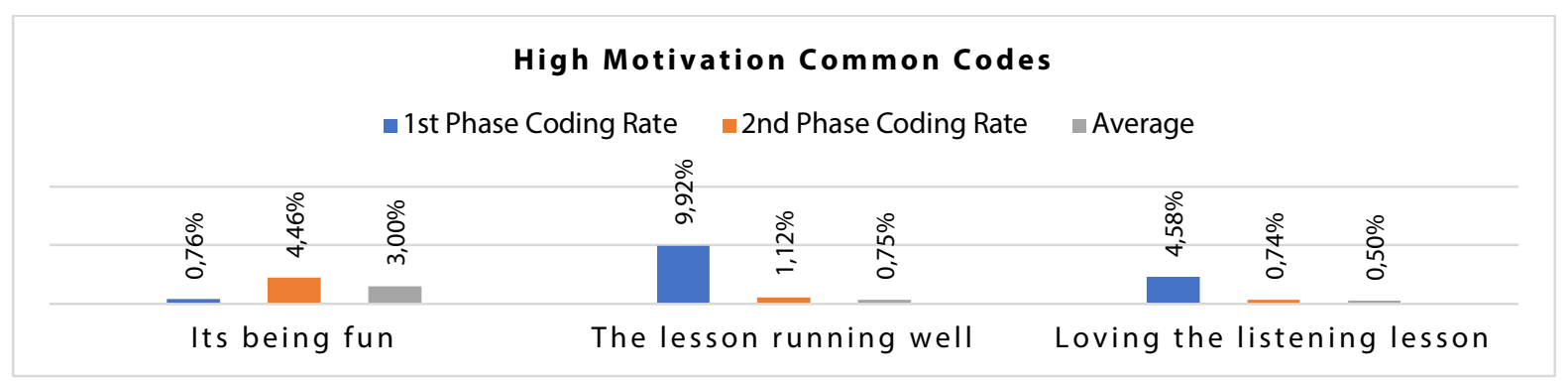

Figure 11. High motivation common codes

Figure 11 comprises of common codes in motivation theme. It's being fun code is among the most effective one on the total with a ratio of $3.00 \%$. The ratio of this code to total code in 1 st phase is $0.76 \%$ and its ratio to the number of codes in 2 nd phase is $4.46 \%$. Lesson running well code's effect on average of all codes is $0.75 \%$. Its ratio to code total in 1 st phase is $9.92 \%$ and its ratio to code total in 2 nd phase is $1.12 \%$. Loving the listening lesson code's effect to average of all codes is $0.50 \%$. Its ratio code total in 1 st phase is $4.58 \%$ and its ratio to code total in 2 nd phase is $0.74 \%$. 


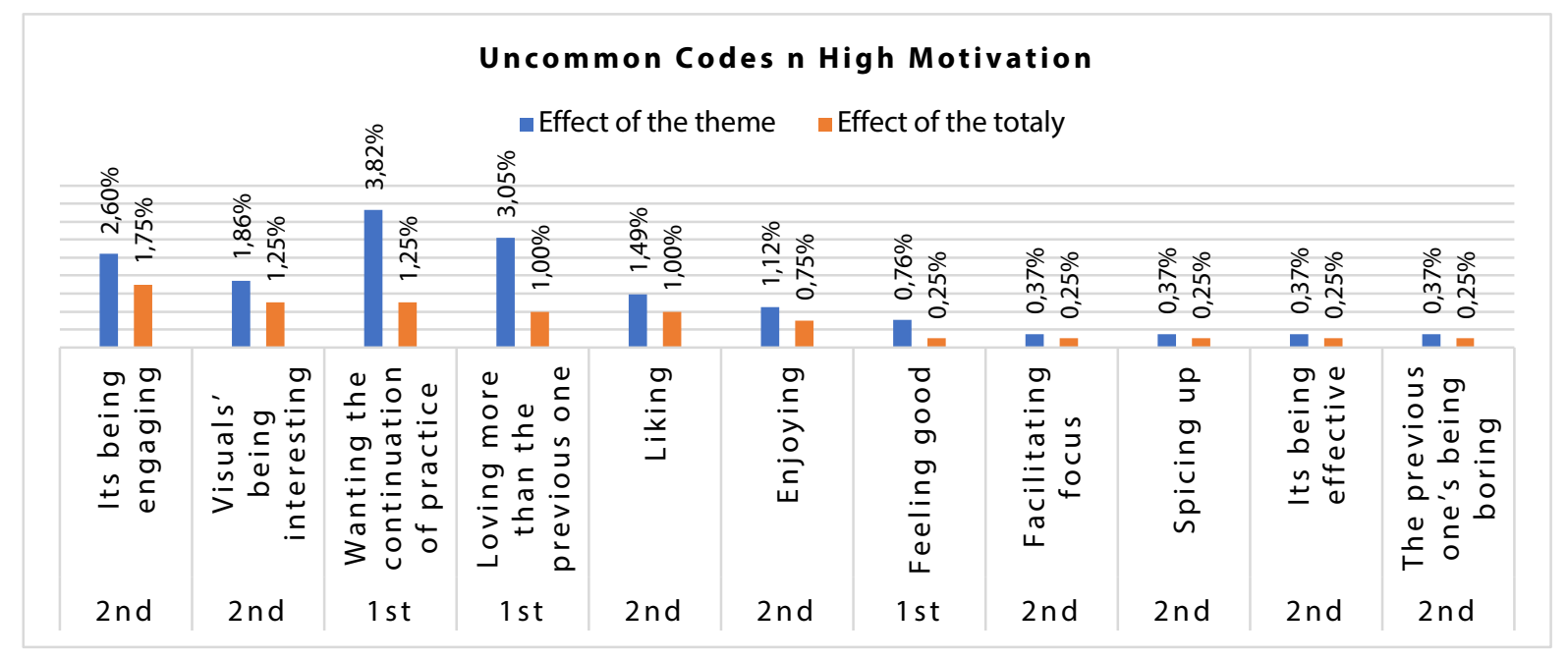

Figure 12. Uncommon codes in high motivation

Codes given in Figure 13 shows the uncommon codes of high motivation theme in 1 st and 2 nd levels. It only exists in the 2 nd phase. Its ratio to the number of codes in 2 nd phase is $2.60 \%$ and its ratio to the number of total codes is $1.75 \%$. Visuals' being interesting, willing to continue to the practice, desiring more than the previous one, liking and enjoying codes are the effective ones in this theme.

\section{Low Motivation Theme}

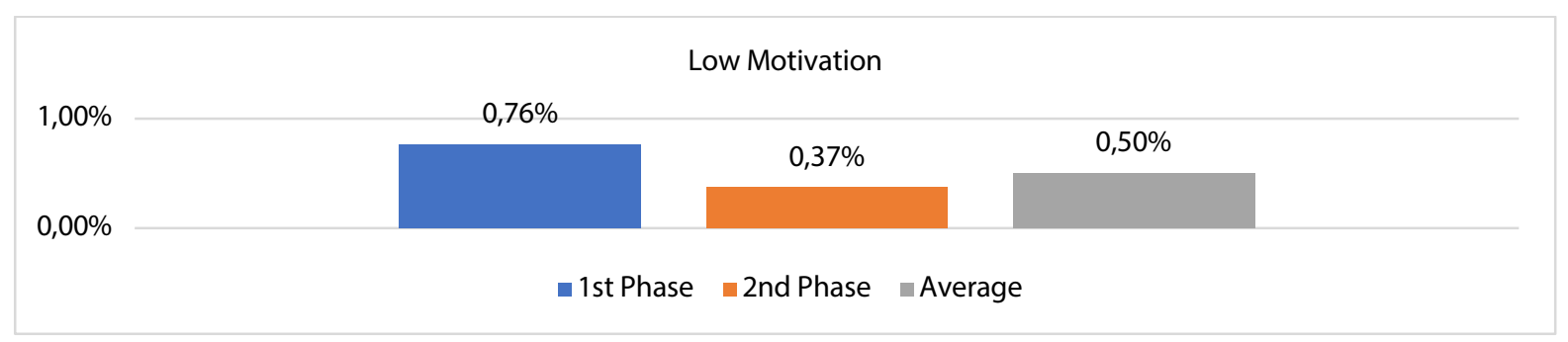

Figure 13. Low motivation

Low motivation theme is the theme gathering opinions on the practice's negative effect on student. Two codes were obtained in total in low motivation theme. This theme's ratio to total code number obtained in 1 st phase is $0.76 \%$ and its ratio to the total code number obtained in 2 nd phase is $0.37 \%$. Its ratio to the total number of codes in both two phases is $0.50 \%$.

\begin{tabular}{|c|c|c|c|}
\hline \multicolumn{4}{|c|}{ Uncommon Codes in Low Motivation } \\
\hline \multirow{3}{*}{$\begin{array}{l}1,00 \% \\
0,50 \% \\
0,00 \%\end{array}$} & $0,25 \%$ & $0,37 \%$ & $0,25 \%$ \\
\hline & $\begin{array}{l}\text { Getting a little bored } \\
\text { 2nd Phs }\end{array}$ & $\begin{array}{r}\text { Not teach } \\
2\end{array}$ & $\begin{array}{l}\text { lesson well } \\
\text { se }\end{array}$ \\
\hline & Effect of the theme & Effect of the totaly & \\
\hline
\end{tabular}

Figure 14. Uncommon codes in low motivation 
Graph 18 shows the uncommon codes of low motivation theme in 1st and 2nd phases. 1st column shows the effect of codes in their own phases, 2nd column shows the two different phases' effect on the total code ratio. There is only one code in each 1 st and 2 nd phases. It is seen that codes' effect on the total is very low.

\section{DISCUSSION}

This study aims to determine the effects of use of DST formatted texts instead of voice records in 2nd language learning listening course on listening skill and lesson. The fact that listening lessons made with DST positively affect learning and it is more effective than the listening lessons made by using voice records, it positively affects student motivation are reflected to research findings. Moreover, it is seen that DST develops listening skills both in creation process (Yuksel, Robin, \& McNeil, 2011; Yang \& Wu, 2012; Yoon, 2016; Aktas \& Yurt, 2017) and as product output (Ramirez-Verdugo \& Belmonte, 2007; (Abidin, Pour-Mohammadi, Souriyavongsa, Tiang, \& Kim, 2011; Cigerci \& Gultekin 2017) in the other studies conducted on listening.

Wide range of opinions related to DST' positive effect on learning environment are reflected to the findings. Half of the research findings are on DST' effect on learning. This ratio and quality of the comments have revealed that DST supports listening education and contributes to learning. It is found that use of DST with multimedia feature instead of voice has positive effects on learning by enriching the learning environment. Frequent repetition of these opinions related to learning proves the effect of DST on learning. Use of different expressions on the effect of DST on learning and wide variety of codes is another evidence presenting its effect on learning. Among these opinions, opinion on DST' facilitating learning is the most repeated one. Facilitating learning code is expressed in different ways such as facilitating learning of DST, pictures, visuals, video and watching. It is highlighted that these concepts giving the names of the codes are the elements creating the multimedia. With these different concepts, the effect of DST' multimedia feature on learning is seen. Another remarkable code regarding the effect on learning is DST' facilitating understanding of a word in the listening lesson. It is seen that multimedia helps guessing the meanings of foreign words and idioms (Mueller, 1980). In the other studies, it is underlined that multimedia facilitates listening skill and word learning (Jones, 2006; Hsu, Hwang, Chang, \& Chang, 2013). If understanding the words and reaching the integrity of the subject accordingly, the first step of listening in learning a foreign language, it can be emphasized that DST helps listening by facilitating word learning. It can be said that understanding words brings about understanding the text. It has been perceived that text and visuals, when used related to audio text, have an easing role in understanding the language (Meskill, 1996). Visuals enable students to see what they know and think, connect and understand new with the known, express them with visual, audio, scientific and strong aspects (Kajder, \& Swenson, 2004). It has been observed that visuals of the content improve level of comprehension, first seeing the visual facilitates understanding of what is listened (Mueller, 1980). There are few negative opinions on learning. It is mentioned that the visuals distract attention and attention is switched to photos. This situation can be explained by students' being dependent on the book. Students' being concerned about answering questions rather than understanding the text causes them to be in a dilemma. This situation can be explained with continuation of habits before the practice. Another remarkable finding is the opinion that the practice may be more effective in lower levels. Accordingly, the 2nd phase practice was made on a lower level of B1. Students' starting to have a command on language shows that they need multimedia support less. In this regard, DST can be regarded as a tool which can be required by basic level students in language teaching. Opinions related to learning showed that stories' roles of informing, teaching and education (Foley, 2013), DST as story's new form can be used as a pedagogic application in listening education (Verdugo \& Belmonte, 2007).

Another theme appears in findings is that comparison of lesson before and after the practice. It can be noted that effectiveness of practice was clearly put forward by making comparison between normal listening lesson and practice lesson. There have been several evaluations on listening lesson based on voice recording and lesson made with DST. In the comparison, many views which can be defined as positive towards lessons with DST were reflected to the findings. The most emphasized view is that listening with DST is better than previous way of listening. It is expressed that this practice is more useful, and the lesson is better understood compared to a normal lesson. The most used expression in comparisons is listening to be good with pictures. 
Students used names reflecting multimedia features instead of DST. It is seen that codes like picture, visual, photograph express the same things. These codes meaning the same things with different concepts reveal that listening lesson with DST is better. There are opinions that can be regarded as negative despite of being in limited number. It is told that it has no difference with normal lesson, there should be old practice. However, this is limited to a couple of opinions of certain students. The comparison theme shows that practice is more effective than the old and has aspects affecting the lesson in a more positive manner.

Another theme obtained with the findings is that lessons made with DST increase student motivation. It is expressed that lesson is fun, goes well and is liked. It is observed that visuals increase students' attention and focus (Mueller, 1980). Students said that the lesson is interesting, effective and enjoyable. It has been found that it is more attractive to use video rather than listening voice recordings in a language class (Shrosbree, 2008). It can be said that motivation increase helped in having a fruitful lesson and getting the desired efficiency from the lesson. The theme exactly the opposite of high motivation is low motivation theme. Comments on low motivation are limited to the comments of a few students. Rareness of codes in a low motivation theme and being limited to a certain extent prove that the practice is effective, and DST provides high motivation.

In learning theme and other themes, there are codes showing that DST' multimedia feature is effective in language learning. In the study of Yoon (2016), it has been revealed that DST as a multimedia tool also supports foreign language development. In the research, it is seen that multimedia develops listening skill (Brett, 1995; Jones \& Plass, 2002; Hernandez, 2004) and facilitates learning of a word (Jones, 2006; Hsu, Hwang, Chang, \& Chang, 2013). This study and other studies have revealed that it is necessary to focus on multimedia in CALL, and to renew visual and audio channels for listening and watching (Hoven, 1999). In terms of multimedia, it is seen that role of computers should be considered (Hoven, 1999). The multimedia providing education possibility can be used in developing listening skills and enrich language education (Meskill, 1996). In this respect, especially DST can be thought as an educational tool. It can be said that the content of DST being an adjustable multimedia tool and being able to be arranged by a teacher provides a major advantage.

\section{CONCLUSION}

This study is designed on the effect of DST with multimedia feature on listening education. Effect of DST, as the new form of story based on listening, on developing listening skill is observed during the process. Instead of only audial voice record, DST which appeals both to listening and watching skills of students was used and its effect was observed. Research findings have revealed that DST is effective on listening education. It is seen that DST is mostly effective on learning. When compared to listening lesson based on voice recording, it is seen that DST is an effective tool. By positively affecting students' motivation, it made learning environment more functional. This practice is limited to DST use in listening education in Turkish teaching to Foreigners in B2 and C1 levels. Similar practices related to DST use can be applied in different language levels in terms of different skill.

\section{BIODATA and CONTACT ADDRESSES of AUTHOR}

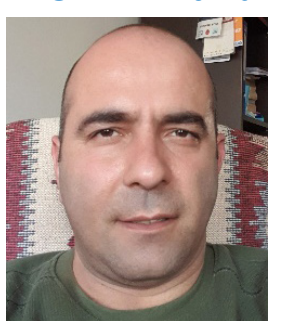

Dr. Fatih TANRIKULU, is assistant professor at the Department of Turkish Education, Kahramanmaras Sutcu Imam University. Dr. Tanrikulu completed his Ph.D. in Turkish Education at Canakkale Onsekiz Mart University in 2014. His academic interest areas are computer assisted language learning, e-learning, L2 language learning and children literature. He has over than 4 journal articles published in national and international indexes, papers submitted to international meetings.

Fatih TANRIKULU

Faculty of Education

Address: Kahramanmaras Sutcu Imam University, Education Faculty, 46050, Kahramanmaras, Turkey

Phone: +903443004439

E-mail: fatih3878@hotmail.com; fatihtanrikulu@ksu.edu.tr 


\section{REFERENCES}

Abidin, M. J. Z., Pour-Mohammadi, M., Souriyavongsa, T., Tiang, C. D. B., \& Kim, N. O. L. (2011). Improving listening comprehension among Malay preschool children using digital stories. International Journal of Humanities and Social Science, 1(14), 159-164.

Abdollahpour Z. \& Maleki N. A. (2012). A Tale of One Story in Two Modes: Digital Flash Stories vs. Printed Stories. Australian Journal of Basic and Applied Sciences, 6(9): 96-101.

Altrichter, H., Posch, P., Somekh, B., \& Feldman, A. (2005). Teachers investigate their work: An introduction to action research across the professions, (5th ed.). New York and London: Routledge.

Aktas, E., \& Yurt, S. U. (2017). Effects of digital story on academic achievement, learning motivation and retention among university students. International Journal of Higher Education, 6(1), 180-196.

Barclay, L.A., 2012. Learning to listen/listening to learn: teaching listening skills to students with visual impairments. New York: AFB Press.

Bauman, R. (1986). Story, performance and event: Contextual studies of oral narrative. Cambridge University Press.

Brett, P. (1995). Multimedia for listening comprehension: The design of a multimedia-based resource for developing listening skills. System, 23(1), 77-85.

Bozdogan, D. (2012). Content analysis of elt students' digital stories for young learners. Novitas-ROYAL, 6(2), 126-136.

Bran R. (2009). Message in a bottle telling stories in a digital world. Procedia Social and Behavioral Sciences, 2, 1790-1793

Bumgarner, B. L. (2012). Digital storytelling in writing: A case study of student teacher attitudes toward teaching with technology. University of Missouri-Columbia.

Castañeda, M. E. (2013). "I am proud that I did it and it's a piece of me": Digital Storytelling in the Foreign Language Classroom. CALICO Journal, 30(1), 44-62.

Cigerci, F. M., \& Gultekin, M. (2017). Use of digital stories to develop listening comprehension skills. Issues in Educational Research, 27(2), 252.

Davis, A., \& McGrail, E. (2009). "Proof-revising" with podcasting: Keeping readers in mind as students listen to and rethink their writing. The Reading Teacher, 62(6), 522-529.

Diaz, M. (2016). Digital Storytelling with Pre-Service Teachers. Raising Awareness for Refugees through ICTS in ESL Primary Classes. Digital Education Review, 30, 1-16.

DIGEM, (2012). A Methodology for Digital Storytelling. http://www.healthy-children.eu/portals/24/ toolbox/box_Training\%20and\%20education/01_Methodology_en.pdf

Dollar, Y. K., \& Tolu, A. T. (2015). My first digital story: a case study with 5th grade Turkish English language learners. ELT Research Journal, 4(3).

Dorner, R., Grimm, P., \& Abawi, D. F. (2002). Synergies between interactive training simulations and digital storytelling: a component-based framework. Computers \& Graphics, 26(1), 45-55.

Ekiz, D. (2009). Bilimsel Arastirma Yontemleri, (2. Baski). Ankara: Ani Yayincilik.

Fasi, M. (2011). Digital storytelling in education. university of kansas. http://people.ku.edu/ -mahah/ mastersplan/digital_storytelling.pdf

Fokides, E. (2016). Using Digital Storytelling to Help First-Grade Students' Adjustment to School. Contemporary Educational Technology, 7(3), 190-205.

Foley, L. M. (2013). Digital storytelling in primary-grade classrooms. Arizona State University.

Gordon, C. J. (2011). Digital storytelling in the classroom: Three case studies (Doctoral dissertation). Arizona State University. 
Gubrium, A. C., \& Scott, T. (2010). Teaching and speaking to social change: A digital storytelling approach addressing access to higher education. Societies Without Borders, 5(2), 126-151.

Hsu, C. K., Hwang, G. J., Chang, Y. T., \& Chang, C. K. (2013). Effects of video caption modes on English listening comprehension and vocabulary acquisition using handheld devices. Journal of Educational Technology \& Society, 16(1), 403.

Hernandez, S. S. (2004). The effects of video and captioned text and the influence of verbal and spatial abilities on second language listening comprehension in a multimedia learning environment (Doctoral dissertation). New York University.

Hoven, D. (1999). A model for listening and viewing comprehension in multimedia environments. Language Learning \& Technology 3 (1), 88-103.

Hull, G. A., \& Katz, M. L. (2006). Crafting an agentive self: Case studies of digital storytelling. Research in the Teaching of English,41(1) 43-81.

Jones, L. C., \& Plass, J. L. (2002). Supporting listening comprehension and vocabulary acquisition in French with multimedia annotations. The modern language journal, 86(4), 546-561.

Jones, L. C. (2006). Effects of collaboration and multimedia annotations on vocabulary learning and listening comprehension. CALICO Journal, 33-58.

Kajder, S., \& Swenson, J. A. (2004). Digital Images In The Language Arts Classroom. In the Curriculum: Language Arts. Learning \& leading with technology, 31(8).

Kemmis, S. \& McTaggart, R. (1992). The Action Research Planner, (3 nd edition). Geelong, Vic.: Deakin University Press, Victoria 1992.

Koshy, V. (2005). Action research for improving practice. London: Paul Chapman Publishing.

Kurudayioglu, M., \& Bal, M. (2014). The Usage of Digital Storytelling in Mother Language Education. Sakarya Universitesi Egitim Fakultesi Dergisi, 28, 74-95.

Long, D. R. (1989). Second language listening comprehension: A schema-theoretic perspective. The Modern Language Journal, 73(1), 32-40.

Lotherington, H. \& N. Ronda 2014. 2B or Not 2B? From Pencil to Multimodal Programming: New Frontiers in Communicative Competencies. In: J. P. Guikema \& L. Williams (eds.), Digital Literacies in Foreign and Second Language Education. San Marcos: CALICO.

Loukia, N. (2006). Teaching young learners through stories: The development of a handy parallel syllabus. The Reading Matrix, 6(1).

McLellan, H. (2007). Digital storytelling in higher education. Journal of Computing in Higher Education, 19(1), 65-79.

Meskill, C. (1996). Listening skills development through multimedia. Journal of Educational Multimedia and Hypermedia, 5(2), 179-201.

Miller, E. A. (2009). Digital storytelling (Master dissertation). University of Northern Iowa.

Miller, C. (2014). Digital storytelling. New York: Routledge.

Morris, R. J. (2011). Responses of listener-viewers in digital storytelling: Collaborations in the intermediate classroom and the middle school library (Doctoral dissertation). University of Pittsburgh.

Mueller, G. A. (1980). Visual contextual cues and listening comprehension: An experiment. The Modern Language Journal, 64(3), 335-340.

Normann, A. (2011). Digital storytelling in second language learning: A qualitative study on students' reflections on potentials for learning (Master Dissertation). Norges Teknisk-Naturvitenskapelige Universitet.

Naughton, M.G. \& Hughes, P. (2009). Doing Action Research in Early Childhood Studies. New York: Open University Press. 
Nguyen, A. (2011). Negotiations and challenges in creating a digital story: The experience of graduate students (Doctoral dissertation). University of Houston.

Ohler, J. (2006). The world of digital storytelling. Educational Leadership, 63, 44-47.

Pardo, B. S. (2014). Digital Storytelling: A case study of the creation, and narration of a story by EFL Learners. Digital Education Review, 26, 74-84.

Robin, B. R., \& McNeil, S. G. (2012). What educators should know about teaching digital storytelling. Digital Education Review, (22), 37-51.

Yuksel, P., Robin, B., \& McNeil, S. (2011). Educational uses of digital storytelling all around the world. In Society for Information Technology \& Teacher Education International Conference, (12641271).

Shrosbree, M. (2008). Digital video in the language classroom. The JALT Call Journal, 4(1), 75-84.

Simsek, B. (2012). Using digital storytelling as a change agent for women's participation in the Turkish public sphere (Doctoral dissertation) Queensland University of Technology.

Stringer, E.T. (2007). Action research (3. Baski). California: Sage Publications.

Tatli, Z ., \& Arzugul Aksoy, D . (2017). Using Digital Storytelling in Foreign Language Speaking Education. Educational Research in International Context, 45 (45), 137-152.

Taylor, C., Wilkie, M., \& Baser, J. (Eds.). (2006). Doing action research: A guide for school support staff. London: SAGE Publications, Incorporated.

Yoon, T. (2012). Are you digitized? Ways to provide motivation for ELLs using digital storytelling. International Journal of Research Studies in Educational Technology, 2(1), 25-34.

Yoon, T. (2016). Improving EFL learners' English skills through computer-mediated language strategy. International Journal of Research Studies in Educational Technology, 5(2).

Tsou W., Wang W. \& Tzeng Y. (2006). Applying a multimedia storytelling website in foreign language learning. Computers \& Education, 47,17-28.

Van Gils, F. (2005). Potential applications of digital storytelling in education. Paper presented at the 3rd Twente Student Conference on IT, Enschede June, 2005.

Vandergrift, L. (2007). Recent developments in second and foreign language listening comprehension research. Language teaching, 40(3), 191-210.

Ramirez Verdugo, D., \& Alonso Belmonte, I. (2007). Using digital stories to improve listening comprehension with Spanish young learners of English. Language Learning \& Technology, 11(1), 87-101.

Wang, S., \& Zhan, H. (2010). Enhancing teaching and learning with digital storytelling. International Journal of Information and Communication Technology Education (IJICTE), 6(2), 76-87.

Yamac, A., \& Ulusoy, M. (2017). The effect of digital storytelling in improving the third graders' writing skills. International Electronic Journal of Elementary Education, 9(1), 59-86.

Yang, Y. T. C., \& Wu, W. C. I. (2012). Digital storytelling for enhancing student academic achievement, critical thinking, and learning motivation: A year-long experimental study. Computers \& education, 59(2), 339-352.

Yuksel-Arslan, P. (2013). Egitim amacli dijital oykunun hazirlanmasi ve kullanilmasi: TPAB temelli ornek bir fen bilgisi egitimi uygulamasi. Fen ve Matematik Egitiminde Teknolojik Pedagojik Alan Bilgisi Temelli Ogretim Tasarimlari. [Preparing and using digital play for educational purposes: A sample science education application based on TPACK. Technological Pedagogical Field Knowledge Based Teaching Designs in Science and Mathematics Education.] Ankara: Ani Yayincilik, 105-128.

Yussof, R. L., Abas, H., \& Paris, T. N. S. T. (2012). Affective engineering of background colour in digital storytelling for remedial students. Procedia-Social and Behavioral Sciences, 68, 202-212. 